\title{
Static sorption of heavy metal ions on ion exchanger in the presence of sodium dodecylbenzenesulfonate
}

\author{
Anna Wołowicz ${ }^{1}$ [ $\cdot$ Katarzyna Staszak $^{2} \cdot$ Zbigniew Hubicki $^{1}$
}

Received: 30 November 2018 / Revised: 4 January 2019 / Accepted: 14 January 2019 / Published online: 1 February 2019

(C) Springer Science+Business Media, LLC, part of Springer Nature 2019

\begin{abstract}
The effect of sodium dodecylbenzenesulfonate (anionic surfactant) on removal of selected heavy metal ions such as copper(II), cobalt(II), zinc(II) and nickel(II) using Lewatit MonoPlus TP 220 were studied. The critical micellization of concentration in the system containing both heavy metal ions and the anionic surfactant was obtained (surface properties). The percentage removal of heavy metal ions in the system without the anionic surfactant was compared with that of heavy metal ions in the presence of the anionic surfactant of the concentration below ( $\downarrow \mathrm{CMC})$ and above $(\uparrow \mathrm{CMC})(\mathrm{HCl}$ - heavy metal ions-anionic surfactant systems). Moreover, Lewatit MonoPlus TP 220 was applied for the heavy metal ions removal from real wastewaters (used a pickling bath) originating from leaching of the heat-resistant nickel and cobalt alloys. The critical micellization of concentration values depends on the composition of solution, presence of hydrochloric acid and heavy metal ions. The presence of the surfactant improves slightly the removal efficiency of cobalt(II) and nickel(II) ions and deteriorates the zinc(II) removal efficiency. Lewatit MonoPlus TP 220 shows high affinity for copper(II) in the model and real wastewater solutions in the case of the systems without and with the anionic surfactant.
\end{abstract}

Keywords Heavy metal ions · Bis-picolylamine resin $\cdot$ Sorption $\cdot$ Recovery $\cdot$ Anionic surfactant

\section{Introduction}

Surfactants (Surface Active Agent) also called amphiphilic compounds or tensides due to their specific structure and utility properties (foaming, wetting, softening, antistatic, caking, emulsifying, adsorptive, solubilizing, thermal and chemical stability) are widely used in industry, washing, laundry, cosmetics, pharmaceuticals, textiles, microelectronics, paints, polymers, as well as in food and paper industry, etc. (Atayi et al. 2002; Kowalska 2009; Shah et al. 2011). The surfactant molecule consists of the non-polar - hydrophobic part (hates water, loves oil) which is usually a long hydrocarbon chain and the polar-hydrophilic part (loves water, hates oil) (Fig. 1). The polar "head" possesses affinity

Anna Wołowicz

anna.wolowicz@poczta.umcs.lublin.pl

1 Department of Inorganic Chemistry, Faculty of Chemistry, Maria Curie-Sklodowska University, Maria Curie-Sklodowska Square 2, 20-031 Lublin, Poland

2 Institute of Chemical Technology and Engineering, Poznan University of Technology, Berdychowo St. 4, 60-965 Poznan, Poland for water and other polar solvents whereas the non-polar "tail" is characterized by affinity for non-polar liquids such as fat. Considering the ability of the polar part of the surface active compound to dissociate in aqueous solutions, the surfactants can be divided into ionic (anionic, cationic, amphoteric and meso-ionic) and nonionic compounds (Fig. 1) (Kowalska 2009).

Among different types of surfactants, anionic ones (AZPC) whose share in global production and sale revenues is the highest, deserve a special attention. They dissociate in aqueous solutions to form an active anion. The anionic group of surfactants is connected to the hydrophobic chain directly or indirectly via covalent bonds, and its acidic nature results in ready formation of salts, and the associated dissolution of the anionic surfactant in water. The AZPC group includes, among others: (a) carboxylates, e.g. alkyl carboxylates, salts of fatty acids, (b) alkyl sulphates, e.g. SLS (sodium lauryl sulphate), alkyl ether sulphates, e.g. SLES (sodium lauryl ether sulfate), (c) sulfonates: sodium sulfosuccinate, alkyl benzene sulfonates, (d) phosphoric acid esters, e.g. alkyl ether phosphates etc. (Cross 1998; Cullum 2012). In 2014 sale revenues of surfactants amounted to over 30 billion USD. The value of the surfactant market is expected to 


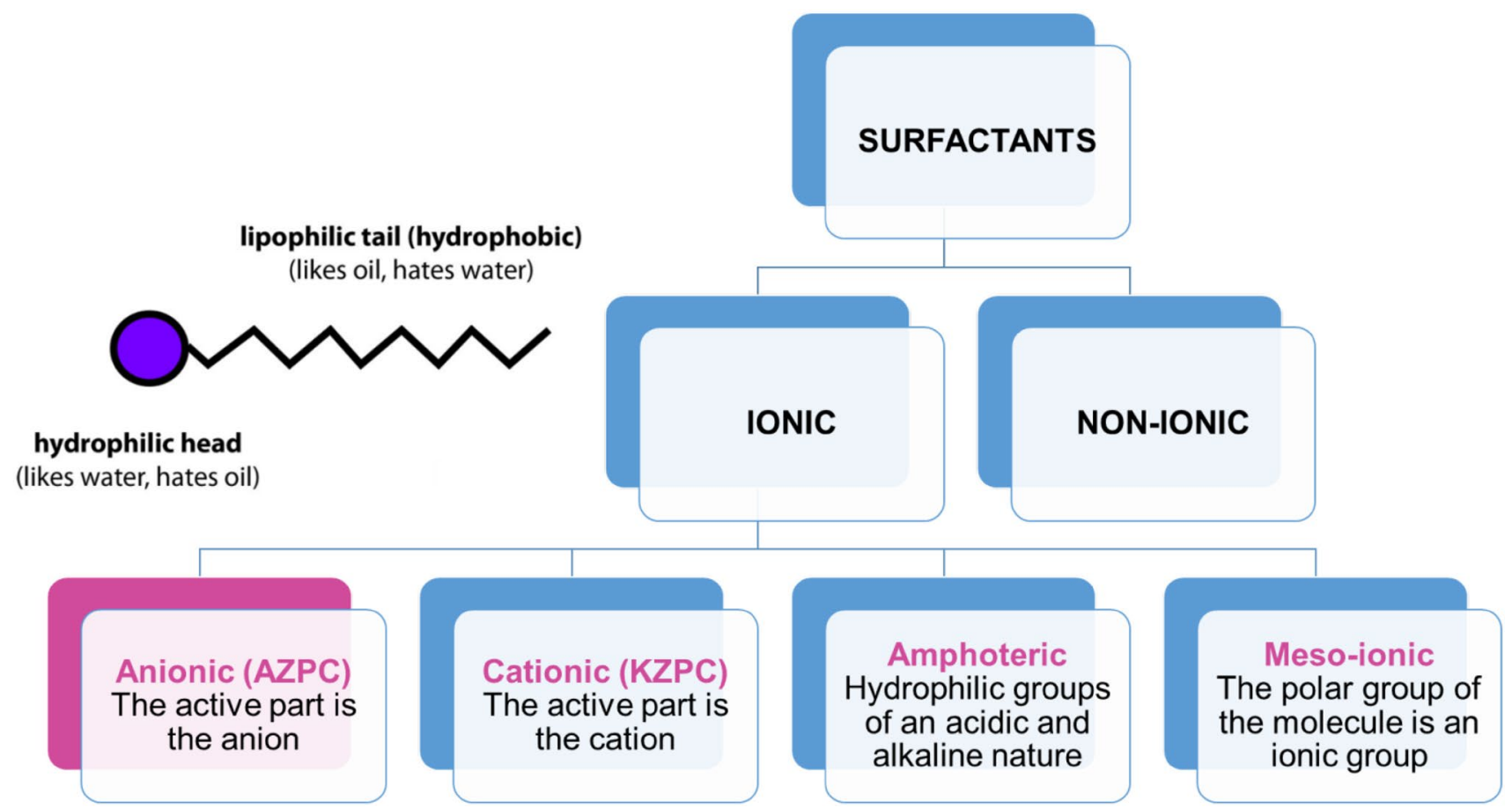

Fig. 1 Division of surface active compounds and scheme of their molecules

grow by an average of $5.8 \%$ per year to reach 40 billion USD in 2019. The increase in revenues will be a consequence of greater consumption of surfactants [in 2014 their global consumption was 17.5 billion tonnes and in 2019 it will be 22.8 billion tonnes (total increase by 30\%)] (Fig. 2) (Markets and Markets 2014).

According to the prediction in Fig. 2, the consumption of surfactants grows year in year out. The largest revenues come from the sale of anionic surfactants whose share in the global production is approximately $50 \div 60 \%$ (Kowalska 2009). The increased demand for surfactants results in the fact that significant amounts can get into the natural environment in the form of various types of wastewaters, produced in washing processes, both as municipal sewages from our households and industrial wastewaters. The harmful effects of surfactants on the natural environment can manifest themselves in several ways: (1) toxic effects on aquatic animal and human organisms - the most toxic surfactants are cationic surfactants but their global production is only $7-10 \%$. Moreover, they are capable of transforming into a non-toxic or precipitated form. On the other hand, anionic surfactants are less toxic compared to the cationic ones but their global production is definitely larger, hence they are a much greater threat. The unfavourable effects of their action on fish are deteriorating the proper function of gills and leading to oxygen deficit, disturbing their proper functioning and transporting various components through these membranes. (2) In the case of humans, people exposed to continuous contacts (a)

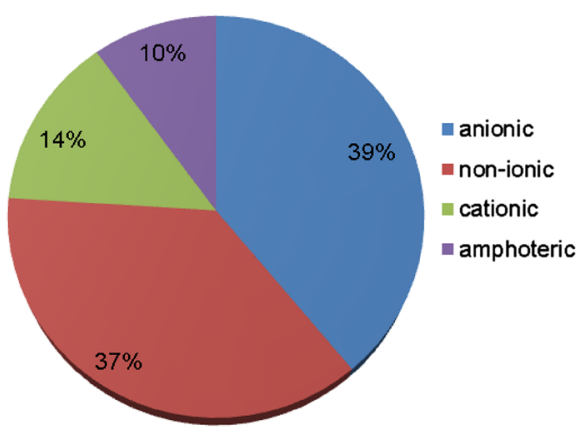

(b)

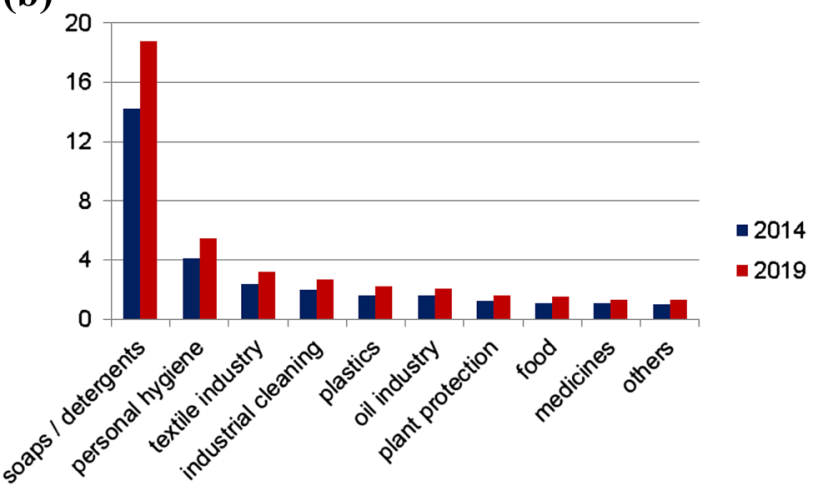

Fig. 2 Global structure of revenues from the sale of surfactants due to a the type in 2014 and $\mathbf{b}$ their application in 2014 and 2019 (in billion USD) 
with surfactants can experience increased tooth decay, damage to the lungs, or vasodilatation. (3) Surfactants limit the penetration of oxygen into natural waters due to their ability to adsorb on the water surface, preventing their proper self-cleaning, hindering development of living organisms and increasing oxygen deficiency due to their biochemical degradation based on oxygen consumption. (4) Surfactants cause foaming of water, disturbance of proper operation of aeration devices in the sewage treatment plants and facilitate the penetration of toxic substances e.g. hydrocarbons, pesticides into the aquatic environment, due to their emulsifying properties causing their better absorption by living organisms (Cserháti et al. 2002; Ivanković and Hrenović 2010; Kowalska 2009).

Taking into account harmful effects of surfactants on living organisms as well as the natural environment and their common application results in huge amounts of wastewaters production, activity in the systems of different compositions (surface properties), their removal as well as effects on removal efficiency of other components of wastewaters are very important. Due to this fact, the aim of the paper was to study the effects of the anionic surfactant on removal of selected heavy metal ions (copper(II), zinc(II), nickel(II) and
cobalt(II)) from acidic solutions using the ion exchange resin Lewatit Mono Plus TP 220. The critical micellization of concentration in the $\mathrm{HCl}-\mathrm{M}$ (II) - anionic surfactant system was obtained. The effectiveness of heavy metal ions removal in the presence of the surfactant of the concentration below $(\downarrow C M C)$ and above ( $\uparrow \mathrm{CMC})$ expressed as the percentage removal (\%R) was compared with \% $\mathrm{R}$ obtained in the system without the surfactant.

\section{Experimental}

\subsection{Anionic surfactant and ion exchange resins characteristics}

The effects of anionic surfactant (sodium alkylbenzene sulfonate, ABS $\mathrm{Na} 50$ ) on heavy metal ions removal using the ion exchange resin Lewatit MonoPlus TP 220 were studied. The characteristics of the ion exchange resin and the anionic surfactant are presented in Fig. 3. The ion exchange resin was washed repeatedly with distilled water and hydrochloric acid before the use. After that this sorbent was dried at ambient temperature to a constant weight.

(a)

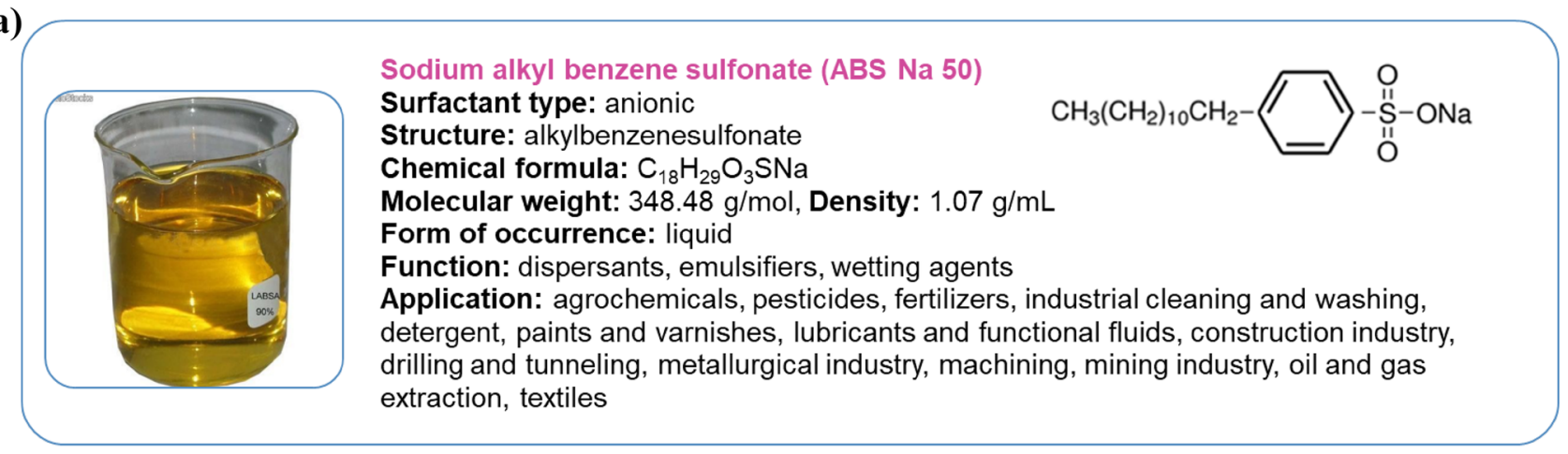

(b)

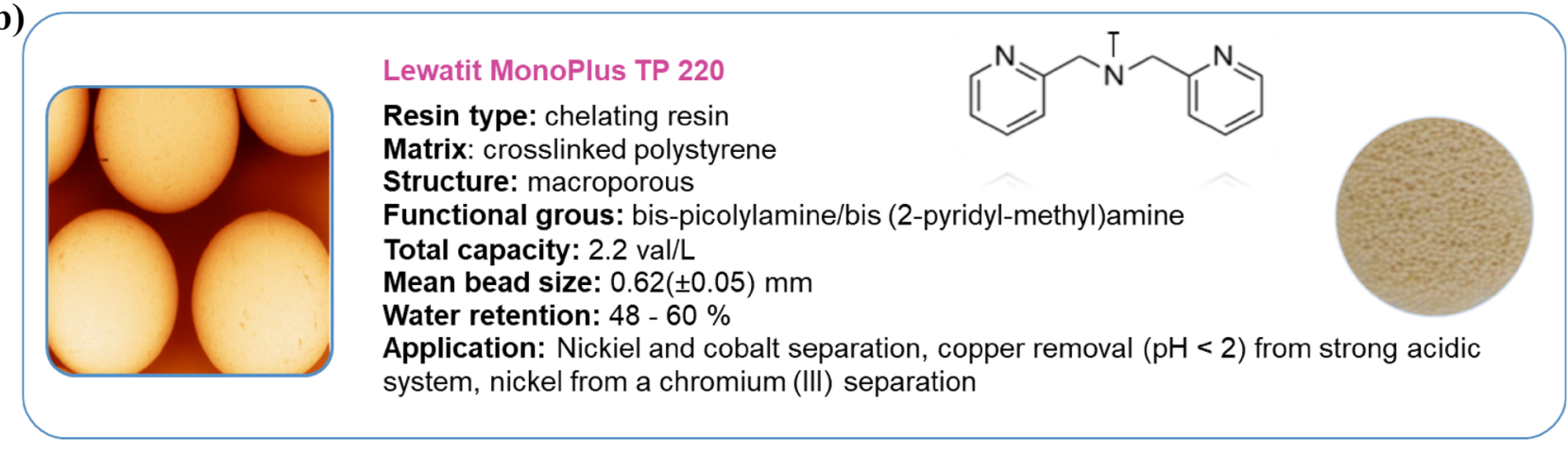

Fig. 3 Characteristics of a anionic surfactant ABS Na 50 and b ion exchange resin Lewatit MonoPlus TP 220 


\subsection{Determination of the critical micelle concentration for the $\mathrm{HCl}-\mathrm{AZPC}$ and $\mathrm{HCl}-$ AZPC-M(II) systems}

The critical concentration of micellization (CMC) for the systems without (HCl-AZPC) and with heavy metal ions $(\mathrm{HCl}-\mathrm{AZPC}-\mathrm{M}(\mathrm{II}))$ was determined on the basis of the plot of equilibrium surface tension versus the decimal logarithm of anionic surfactant concentration - the surface tension isotherms, $\gamma[\mathrm{mN} / \mathrm{m}]$ versus $\log (\mathrm{c})[\mathrm{mol} / \mathrm{L}]$. The measurements of the equilibrium surface tension were made at a constant temperature of $294 \mathrm{~K}$ using a simple experimental method that is the du Noüy ring method (K12 tensiometer from Krúss (Germany) with the resolution $0.01 \mathrm{mN} / \mathrm{m}$ ). This method is preferable due to its availability, rapid and easy procedure as well as low cost. It is based on measuring the maximum force needed to raise the Pt-Ir alloy ring from the surface of the tested liquid. The ring was rinsed in the water from the PURELAB Classic, Elga with the resistivity $=18.2 \mathrm{M} \Omega \mathrm{cm}$ or in the hydrochloric acid solution of different concentrations before each measurement (depending on the solution composition). The measurements were repeated three times. Then the average surface tension value was obtained (Shen et al. 2015). The measurements were made for the aqueous solution of proper composition at the initial surfactant concentration equal to $2.55 \mathrm{~g} / \mathrm{L}$. The other solutions were prepared by the dilution method. The concentration of heavy metal ion was equal to $100 \mathrm{mg} \mathrm{M}(\mathrm{II}) / \mathrm{L}$ and the concentrations of hydrochloric acid were $0.1 ; 1 ; 3$ and $6 \mathrm{~mol} / \mathrm{L}$.

\subsection{Sorption studies: batch test}

The process of heavy metal ions $\mathrm{Ni}(\mathrm{II}), \mathrm{Co}(\mathrm{II}), \mathrm{Cu}$ (II), $\mathrm{Zn}$ (II) removal in the presence of the anionic surfactant ABS Na 50 was conducted using the static method.

The experimental procedure was as follows:

(1) Preparation of stock solutions of $\mathrm{HCl}-\mathrm{AZPC}$ and $\mathrm{HCl}-\mathrm{AZPC}-\mathrm{M}(\mathrm{II})$. The concentration of ABS Na 50 surfactant was chosen so that in all systems it was above and below CMC (( $\uparrow \mathrm{CMC}),(\downarrow \mathrm{CMC}))$. The hydrochloric acid concentration was $0.1 ; 1 ; 3 ; 6 \mathrm{~mol} / \mathrm{L}$, the concentration of metal ions (II) was $100 \mathrm{mg} / \mathrm{L}$ in each case whereas that of ABS Na 50 surfactant was $18 \mathrm{mg} / \mathrm{L}$ ( $\downarrow$ CMC) and $2550 \mathrm{mg} / \mathrm{L}$ ( $\uparrow \mathrm{CMC}$ ).

(2) Conducting the process of heavy metal ions removal without and with the surfactant $-0.05 \mathrm{~L}$ of proper solution (e.g. $0.1 \mathrm{M} \mathrm{HCl}-100 \mathrm{mg} \mathrm{Cu}(\mathrm{II}) / \mathrm{L}-\mathrm{ABS} \mathrm{Na} 50$ ( $\uparrow \mathrm{CMC}$ ), $0.1 \mathrm{M} \mathrm{HCl}-100 \mathrm{mg} \mathrm{Cu}(\mathrm{II}) / \mathrm{L}-\mathrm{ABS} \mathrm{Na} 50$ ( $\downarrow \mathrm{CMC}$ ) etc.) was shaken for $24 \mathrm{~h}$ at room temperature with the addition of $0.5 \pm 0.0005 \mathrm{~g}$ of the ion exchanger [shaking speed $=180$ spm, amplitude $=8$ using the mechanical shaker Elphin+, type 357 (Lubawa, Poland)]. Then the phases were separated by filtration. The procedure was repeated for the solution with or without the surfactant.

(3) Determination of the content of anionic surfactant and metal(II) ions in the solution after the sorption process (surfactant-by measuring the surface tension from the dependence $\gamma[\mathrm{mN} / \mathrm{m}]$ from $\log (\mathrm{c})[\mathrm{mol} / \mathrm{L}], \gamma=\mathrm{a} \bullet \mathrm{x}+\mathrm{b})$, the concentration of heavy metal ions - using the atomic absorption spectrometry (AAS) method and the spectrometer Varian AA240FS (Varian, Australia).

(4) Comparison of removal efficiency (\% R) of heavy metal ions from the systems without and with the surfactant.

The percentage removal $(\% \mathrm{R})$ of heavy metal ions was calculated using Eq. 1 (Budak 2013):

$\% R=\frac{C_{0}-C_{t}}{C_{0}} \cdot 100 \%$

where: $C_{0}$ is the initial (starting) concentration of the surfactant or heavy metal ions, i.e. before the sorption process $(\mathrm{mg} / \mathrm{L})$ and $\mathrm{C}_{\mathrm{t}}$ is the concentration of surfactant or heavy metal ions in the solution after the sorption process $(\mathrm{mg} / \mathrm{L})$.

\subsection{Removal of heavy metal ions from metallurgical wastewaters}

Lewatit MonoPlus TP 220 was applied in heavy metal ions removal from acidic industrial wastewater, supplied by a company specializing in the utilization of industrial waste using the batch method. The characterisation e.g. composition of wastewaters, the content of $\mathrm{H}^{+}$ions, $\mathrm{pH}$ of solution was made. Then Lewatit MonoPlus TP 220 was applied for heavy metal ions removal from real solutions. Additionally, the effects of ABS Na 50 on heavy metal ions removal from the metallurgical wastewaters were analyzed.

\section{Results and discussion}

\subsection{Surface tension measurements as a function of ABS Na 50 concentration and determination of the critical micelle concentration}

First of all, the surface tension of solvent (water, hydrochloric acid of different concentrations $-0.1,1,3,6 \mathrm{~mol} / \mathrm{L}$ ) was obtained in triplicate using the du Noüy ring method. Then the same procedure was applied for all other samples. For each test, $20 \mathrm{~mL}$ of solutions was used and put into a glass crystallizer without nozzle. The parameters such as the air and solvent density at room temperature were put in manually and changed before the next series of solutions. The surface tension measurements were made for the following solution series: (1) for the ABS Na 50 system in different solvents: in water ABS Na 50; $0.1 \mathrm{~mol} / \mathrm{L} \mathrm{HCl}-\mathrm{ABS} \mathrm{Na}$ 
$50 ; 1 \mathrm{~mol} / \mathrm{L} \mathrm{HCl}-\mathrm{ABS} \mathrm{Na} 50 ; 3 \mathrm{~mol} / \mathrm{L} \mathrm{HCl}-\mathrm{ABS} \mathrm{Na}$ $50 ; 6 \mathrm{~mol} / \mathrm{L}-\mathrm{ABS} \mathrm{Na} 50$ and (2) for the ABS Na 50 system in different solvents with the heavy metal ions addition of $100 \mathrm{mg} / \mathrm{L}$ concentration: in water $\mathrm{Cu}(\mathrm{II})$ - ABS Na $50 ; 0.1 \mathrm{~mol} / \mathrm{L} \mathrm{HCl}-\mathrm{Cu}(\mathrm{II})$ - ABS Na $50 ; 1 \mathrm{~mol} / \mathrm{L} \mathrm{HCl}-$ $\mathrm{Cu}(\mathrm{II})$ - ABS Na 50; $3 \mathrm{~mol} / \mathrm{L} \mathrm{HCl}-\mathrm{Cu}(\mathrm{II})-\mathrm{ABS} \mathrm{Na} 50$; $6 \mathrm{~mol} / \mathrm{L} \mathrm{HCl}-\mathrm{Cu}(\mathrm{II})-\mathrm{ABS} \mathrm{Na} 50$ etc. The selected heavy metal ions were copper(II), cobalt(II), nickel(II) and zinc(II).

The surface tension of the water from the PURELAB Classic obtained by the du Noüy method was $\Upsilon_{0}=71.41( \pm 1.04) \mathrm{mN} / \mathrm{m}$ (the standard deviation was given in parentheses) and was similar to the other surface tension values presented in the literature. Lee et al. (2012) presented the surface tension of deionised distilled water obtained using four methods such as du Noüy ring method, drop weight method, HB correction factors method and LCP coefficient method. The surface tension values $(\mathrm{mN} / \mathrm{m})$ were following: $73.05( \pm 0.05)$ (du Noüy ring method); $71.34( \pm 1.29)$ (HB correction factors method), 72.83( \pm 0.17 ) (LCP coefficient method), 71.98 (reference value). The surface tension values obtained for hydrochloric acid as a solvent were 70.92( \pm 1.27$) \mathrm{mN} / \mathrm{m}(0.1 \mathrm{M} \mathrm{HCl}), 70.91( \pm 1.11)$ $\mathrm{mN} / \mathrm{m}(1 \mathrm{M} \mathrm{HCl}), 70.82( \pm 0.39) \mathrm{mN} / \mathrm{m}(3 \mathrm{M} \mathrm{HCl})$ and $70.17( \pm 1.89) \mathrm{mN} / \mathrm{m}(6 \mathrm{M} \mathrm{HCl})$. As it was found by Matubayasi et al. (2003) and Baldelli et al. (1999) the presence of $\mathrm{HCl}$ acid affects the surface properties of the system which results in the changes of surface tension values. In the $\mathrm{HCl}$ system the addition of $\mathrm{HCl}$ molecules into water results in partial dissolution and dissociation into $\mathrm{H}^{+}$and $\mathrm{Cl}^{-}$but a portion remains in the molecular form. Therefore the surface region includes water, air, $\mathrm{HCl}, \mathrm{H}^{+}$and $\mathrm{Cl}^{-}$. From the thermodynamic point of view the changes of surface tension can be expressed as a function of the chemical potential of all constituents (Matubayasi et al. 2003). The presence of molecular $\mathrm{HCl}$ was not shown by Baldelli et al. (1999) (no signal of molecular $\mathrm{HCl}$ ) using the direct spectrophotometric method (sum frequency generation (SFG) spectroscopy) who explained that ions in solution results in reorientation of water on the surface compared to pure water (hydrogen atoms are orientated towards the bulk solutions) results in domination of the surface by the orientated water molecules. Matubayasi et al. (2003) using the thermodynamic treatment stated that the results obtained by Baldelli et al. (1999) could be true for the positive adsorption of the system containing volatile acids-nitric acid and acetic acid and that of undissociated $\mathrm{HCl}$ can occur just above the water surface.

Based on the surface tension values for the hydrochloric acid solutions it was found that with the hydrochloric acid concentration increase, the surface tension of solutions, $\Upsilon_{0}$ decreases slightly. A similar observation was made by NasrEl-Din et al. (2004) at a temperature equal to $298 \mathrm{~K}$ as a result of changes in water molecules orientation at the air/ liquid interface.

Changes occurring at the interface and in the bulk phase are presented by means of the surface tension isotherm, usually as a function of the logarithm of surfactant concentration. The surface tensions obtained for the solutions containing sodium dodecylbenzenesulfonate such as ABS Na 50; $\mathrm{HCl}-\mathrm{ABS} \mathrm{Na} 50$ and $\mathrm{HCl}-\mathrm{M}(\mathrm{II})-\mathrm{ABS} \mathrm{Na} 50$ are presented as the adsorption isotherm plots. The schematic changes of surface tension as a function of surfactant concentration are presented in Fig. 4 whereas the surface tension

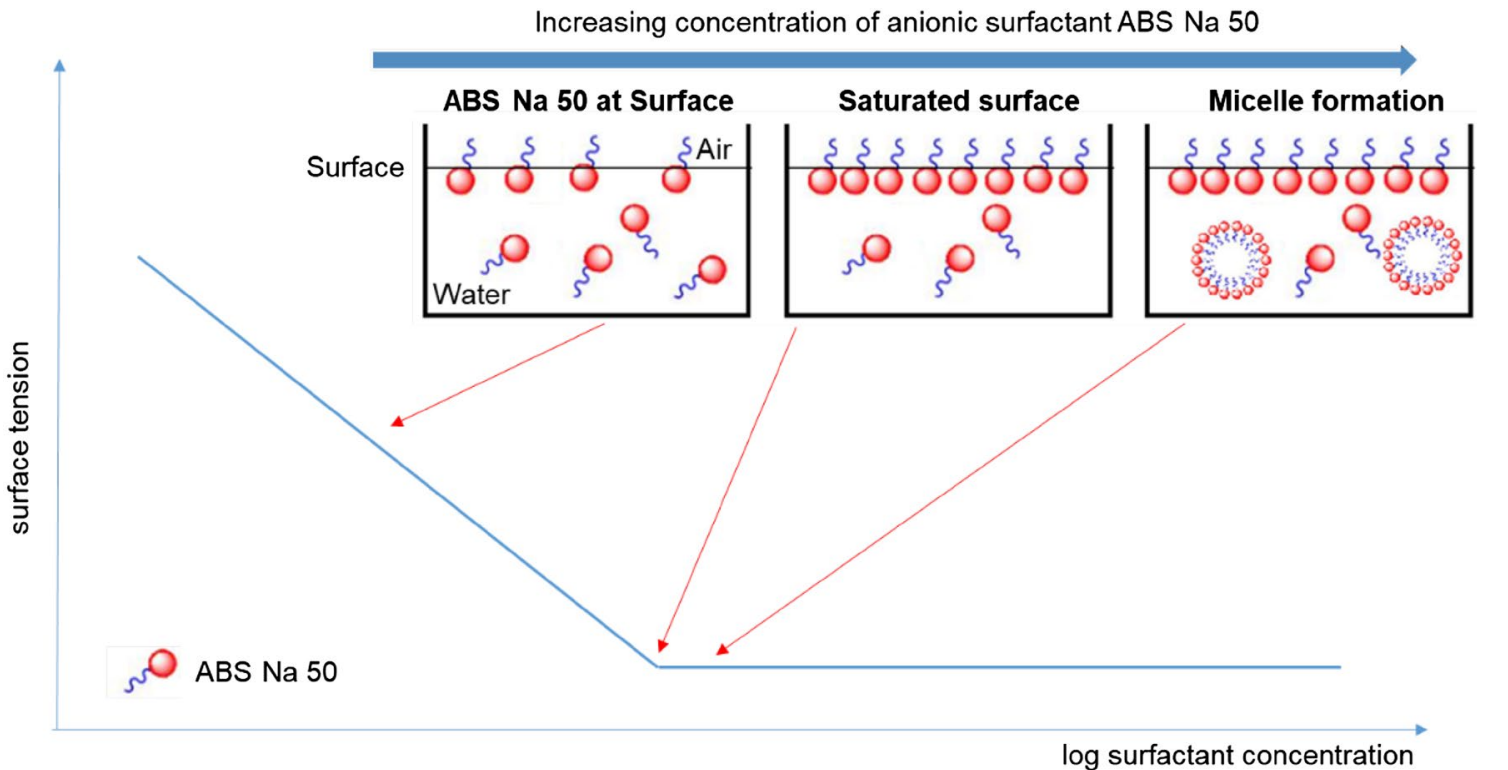

Fig. 4 Changes of surface tension as a function of the surfactant concentration 
isotherms, $\gamma[\mathrm{mN} / \mathrm{m}]$ versus $\log (\mathrm{c})[\mathrm{mol} / \mathrm{L}]$ are shown in Fig. 5 (only chosen examples from 25 isotherms).

The presented surface tension isotherm shows the adsorption process taking into account three stages: (1) gradual adsorption of the surfactant at the interface, (2) saturation of the interface and (3) formation of micelles. In the dilute solutions, surfactants are present in the form of single ions or molecules (monomers). In the more concentrated solutions, as a result of self-association, these molecules merge into clusters forming the so-called micelles. Micellisation occurs after exceeding the critical micelle concentration (CMC) which is characteristic of a given surfactant. The micelles produced in the solution cause changes in the surface tension or solution viscosity and can exist in various forms, depending on the orientation of the monomers. Depending on the concentration of the surfactant in the solution, spherical, vesicular, cylindrical and bilayer micelles could be formed (Schramm 2000).

Based on the adsorption isotherms (Fig. 5) the critical micelle concentration (CMC) was determined experimentally by extrapolation of the experimental data in the place where the curve collapsed. The straight lines were drawn through the experimental points from the second and third parts of the plots and the critical micelle concentration was obtained from the point of lines intersection. The values of the critical micelle concentration for the ABS Na 50; HClABS Na 50, M(II)—ABS Na 50, HCl-M(II)—ABS Na 50 system are collected in Table 1 where $\mathrm{M}$ is $\mathrm{Cu}(\mathrm{II}), \mathrm{Co}(\mathrm{II})$, $\mathrm{Ni}(\mathrm{II})$ or $\mathrm{Zn}(\mathrm{II})$.

The CMC value obtained for the sodium dodecylbenzenesulfonate surfactant in water was equal to $1.52 \mathrm{mmol} / \mathrm{L}$. Perkowski et al. (2012) obtained also the CMC value of ABS Na 50 using the spectrofluorometric method which is in a good agreement with our results $(1.58 \mathrm{mmol} / \mathrm{L})$. This CMC value is the highest in the system without $\mathrm{HCl}$ whereas the CMC values decrease significantly with the hydrochloric acid addition and decrease slightly with the increasing hydrochloric acid concentration from 0.1 to $6 \mathrm{~mol} / \mathrm{L}$. The reduction of CMC is by above $91 \% \mathrm{com}-$ pared with the solutions without $\mathrm{HCl}$ and with $0.1 \mathrm{~mol} / \mathrm{L}$ $\mathrm{HCl}$. The decrease in the $\mathrm{CMC}$ values with the addition of electrolyte was reported in the literature e.g. CMC determination of SDS, Triton X-100 - the addition of $\mathrm{NaCl}$ salts $(0,2,4$ and $6 \mathrm{wt} \%)$ (Muherei and Junin 2007), cocamidopropyl betaine (CAPB) - the addition of sodium chloride (0-2 mol/L) (Staszak et al. 2015) etc. The electrolyte causes weakening of electrostatic repulsions between the charged hydrophilic groups and make the surfactant more hydrophobic. This increases hydrophobic interactions among the surfactant monomers and results in their aggregation at lower concentration, thereby the CMC decreases (Muherei and Junin 2007). As mentioned previously in the case of strong electrolyte e.g. hydrochloric acid, $\mathrm{H}^{+}$and $\mathrm{Cl}^{-}$ions as well as $\mathrm{HCl}$ molecules are present in the systems under consideration which results in changes of CMC values. The $\mathrm{CMC}$ values depends also on the presence and type of heavy metal ions in the systems. For example, the CMC values in the systems without $\mathrm{HCl}$ can be arranged as follows: $\mathrm{ABS}$ Na 50-M(II): $\mathrm{Cu}(\mathrm{II})<\mathrm{Ni}(\mathrm{II})<\mathrm{Zn}$ (II) $<\mathrm{Co}$ (II) $<$ no metal. The presence of heavy metal ions ( $\mathrm{HCl}-\mathrm{M}$ (II) - ABS Na 50 systems) causes a decrease or increase in the CMC values compared with the systems without heavy metal ions. This change may be caused by the formation of surfactant-metal aggregates/micelles. CMC usually increases with the reduction of the atomic number of the counter ions ${ }_{27} \mathrm{Co},{ }_{28} \mathrm{Ni}$, ${ }_{29} \mathrm{Cu},{ }_{30} \mathrm{Zn}$ but in these systems this tendency is not observed (Akhter 1995).

\subsection{Sorption of surfactant and heavy metal ions in the presence of ABS $\mathrm{Na} 50$ by Lewatit MonoPlus TP 220}

Lewatit MonoPlus TP 220 was previously applied for heavy metal ions sorption (Wołowicz and Hubicki 2012) from the acidic solutions (hydrochloric acid solutions of the increasing concentration from 0.1 to $6 \mathrm{~mol} / \mathrm{L}$ ). The characteristics of Lewatit MonoPlus TP 220 is presented in Fig. 3 and can be found in the other published paper e.g. elementary $\mathrm{CHN}$ analysis (Perkin Elmer CHN 2400 analyzer and the Sartorius microbalance M2P), surface morphology using the scanning electron BS: 301 (Telsa) and atomic force NanoScope V (Veeco, USA) microscopes, FT-IR analysis results in bispicolylamine functional groups confirmation (Wołowicz and Hubicki 2012; Kołodyńska et al. 2014). As it was proved the ion exchange resin exhibits high affinity for copper(II) ions and other base metals. The selectivity series were as follows: $\mathrm{Cu}$ (II) $\left(\mathrm{q}_{\mathrm{e}}=9.98 \mathrm{mg} / \mathrm{g}\right)>\mathrm{Zn}($ II $)\left(\mathrm{q}_{\mathrm{e}}=9.09 \mathrm{mg} / \mathrm{g}\right)>\mathrm{Co}$ (II) $\left(\mathrm{q}_{\mathrm{e}}=6.90 \mathrm{mg} / \mathrm{g}\right) \approx \mathrm{Ni}(\mathrm{II})\left(\mathrm{q}_{\mathrm{e}}=6.24 \mathrm{mg} / \mathrm{g}\right)-0.1 \mathrm{~mol} / \mathrm{L} \mathrm{HCl}$; $\mathrm{Cu}(\mathrm{II})>\mathrm{Zn}$ (II) $>\mathrm{Ni}(\mathrm{II}) \approx \mathrm{Co}$ (II) -1 and $3 \mathrm{~mol} / \mathrm{L} \mathrm{HCl} ; \mathrm{Zn}$ (II) $\left(\mathrm{q}_{\mathrm{e}}=9.15 \mathrm{mg} / \mathrm{g}\right) \approx \mathrm{Cu}(\mathrm{II})\left(\mathrm{q}_{\mathrm{e}}=9.12 \mathrm{mg} / \mathrm{g}\right)>\mathrm{Co}(\mathrm{II})\left(\mathrm{q}_{\mathrm{e}}=\right.$ $6.62 \mathrm{mg} / \mathrm{g})>\mathrm{Ni}(\mathrm{II})\left(\mathrm{q}_{\mathrm{e}}=4.89 \mathrm{mg} / \mathrm{g}\right)-6 \mathrm{~mol} / \mathrm{L} \mathrm{HCl}($ AAS method with the parameters: the wavelength [nm]: 232.0, 213.9, 324.8, 240.7; the lamp current [mA]: 4, 5, 4, 7; slit width [nm]: $0.2,1.0,0.5,0.2$ for $\mathrm{Ni}(\mathrm{II}), \mathrm{Zn}(\mathrm{II}), \mathrm{Cu}$ (II), $\mathrm{Co}$ (II) respectively and the air/acetylene flow [L/min]: 13.5/2). Moreover, Lewatit MonoPlus TP 220 exhibits good kinetics and the time required to reach equilibrium was in the range 60-240 min. Quantitative removal of copper(II) ions (\% close to $100 \%$ ) and good sorption efficiency for other heavy metal ions make this ion exchange resin extremely attractive from a practical point of view. Therefore in the next subchapter the results of heavy metal ions removal from real industrial solutions are presented. The mechanism of sorption and explanation of high sorption efficiency towards heavy metal ions were presented previously (Wołowicz and Hubicki 2012). 

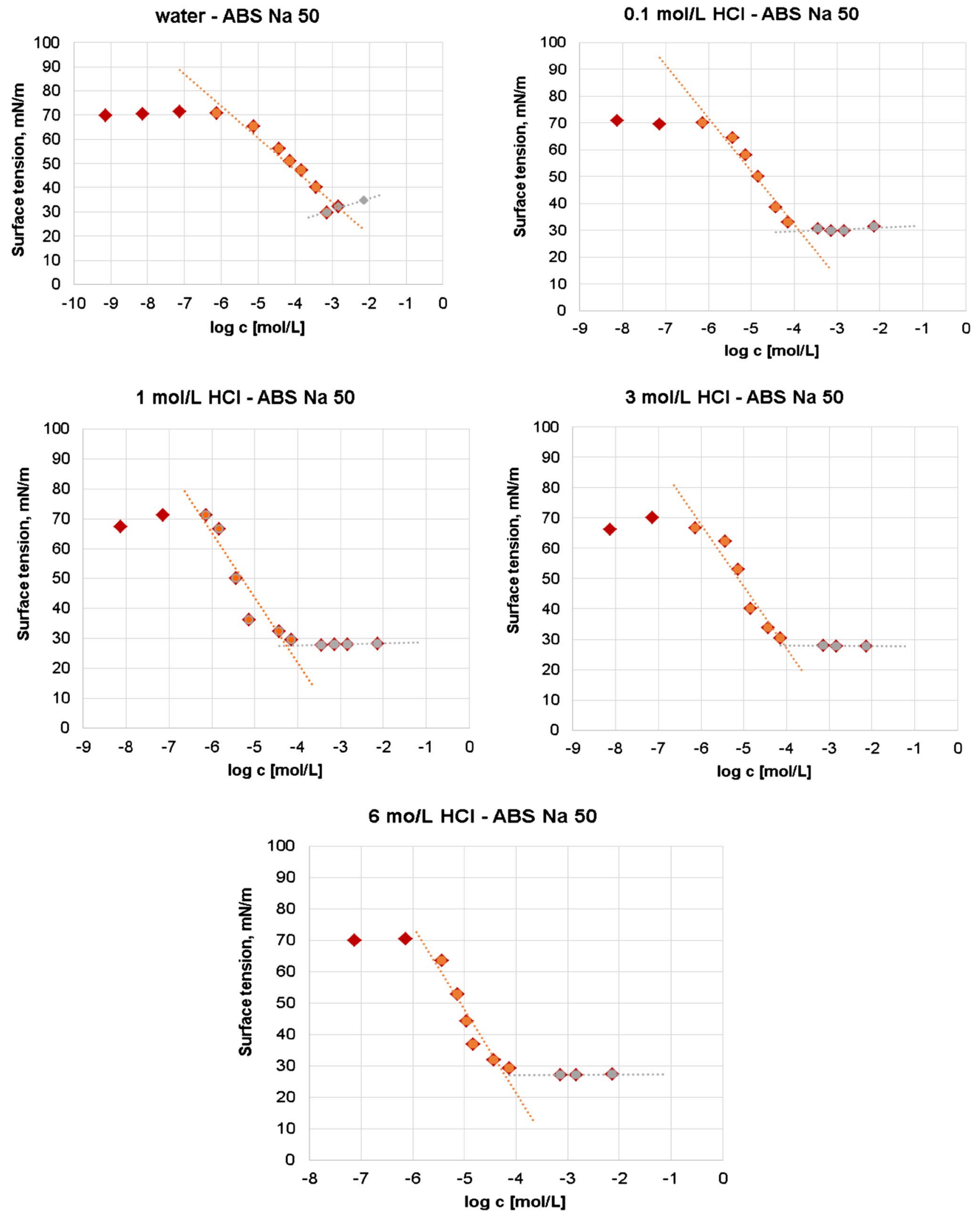

Fig. 5 Plots of equilibrium surface tension as a function of decimal logarithm of concentration for the water-100 mg Cu(II)/L-ABS Na 50 and $\mathrm{HCl}-100 \mathrm{mg} \mathrm{Cu}(\mathrm{II}) / \mathrm{L}-\mathrm{ABS}$ Na 50 systems 
Table 1 Comparison of the critical micelle concentration values obtained for the systems containing the sodium dodecylbenzenesulfonate surfactant

\begin{tabular}{|c|c|c|c|c|}
\hline \multicolumn{3}{|l|}{ Systems } & \multirow[t]{2}{*}{$\log c$} & \multirow[t]{2}{*}{$\mathrm{CMC}(\mathrm{mmol} / \mathrm{L})$} \\
\hline Solvent & Heavy metal & Surfactant & & \\
\hline Water & - & ABS Na 50 & -2.82 & 1.52 \\
\hline $0.1 \mathrm{~mol} / \mathrm{L}$ & - & ABS Na 50 & -3.87 & 0.13 \\
\hline $1.0 \mathrm{~mol} / \mathrm{L}$ & - & ABS Na 50 & -4.25 & 0.06 \\
\hline $3.0 \mathrm{~mol} / \mathrm{L}$ & - & ABS Na 50 & -4.00 & 0.10 \\
\hline \multirow[t]{2}{*}{$6.0 \mathrm{~mol} / \mathrm{L}$} & - & ABS Na 50 & -4.21 & 0.06 \\
\hline & & & $\log c$ & $\mathrm{CMC}(\mathrm{mmol} / \mathrm{L})$ \\
\hline Water & $\mathrm{Cu}(\mathrm{II})$ & ABS Na 50 & -3.74 & 0.18 \\
\hline $0.1 \mathrm{~mol} / \mathrm{L}$ & $\mathrm{Cu}(\mathrm{II})$ & ABS Na 50 & -3.81 & 0.15 \\
\hline $1.0 \mathrm{~mol} / \mathrm{L}$ & $\mathrm{Cu}(\mathrm{II})$ & ABS Na 50 & -4.03 & 0.09 \\
\hline $3.0 \mathrm{~mol} / \mathrm{L}$ & $\mathrm{Cu}(\mathrm{II})$ & ABS Na 50 & -4.29 & 0.05 \\
\hline \multirow[t]{2}{*}{$6.0 \mathrm{~mol} / \mathrm{L}$} & $\mathrm{Cu}(\mathrm{II})$ & ABS Na 50 & -4.16 & 0.07 \\
\hline & & & $\log c$ & $\mathrm{CMC}(\mathrm{mmol} / \mathrm{L})$ \\
\hline Water & $\mathrm{Zn}(\mathrm{II})$ & ABS Na 50 & -3.64 & 0.23 \\
\hline $0.1 \mathrm{~mol} / \mathrm{L}$ & $\mathrm{Zn}(\mathrm{II})$ & ABS Na 50 & -3.71 & 0.20 \\
\hline $1.0 \mathrm{~mol} / \mathrm{L}$ & $\mathrm{Zn}(\mathrm{II})$ & ABS Na 50 & -4.14 & 0.07 \\
\hline $3.0 \mathrm{~mol} / \mathrm{L}$ & $\mathrm{Zn}(\mathrm{II})$ & ABS Na 50 & -4.22 & 0.06 \\
\hline \multirow[t]{2}{*}{$6.0 \mathrm{~mol} / \mathrm{L}$} & $\mathrm{Zn}(\mathrm{II})$ & ABS Na 50 & -4.26 & 0.06 \\
\hline & & & $\log c$ & $\mathrm{CMC}(\mathrm{mmol} / \mathrm{L})$ \\
\hline Water & $\mathrm{Ni}(\mathrm{II})$ & ABS Na 50 & -3.67 & 0.22 \\
\hline $0.1 \mathrm{~mol} / \mathrm{L}$ & $\mathrm{Ni}(\mathrm{II})$ & ABS Na 50 & -3.85 & 0.14 \\
\hline $1.0 \mathrm{~mol} / \mathrm{L}$ & $\mathrm{Ni}(\mathrm{II})$ & ABS Na 50 & -4.07 & 0.09 \\
\hline $3.0 \mathrm{~mol} / \mathrm{L}$ & $\mathrm{Ni}(\mathrm{II})$ & ABS Na 50 & -4.21 & 0.06 \\
\hline \multirow[t]{2}{*}{$6.0 \mathrm{~mol} / \mathrm{L}$} & $\mathrm{Ni}(\mathrm{II})$ & ABS Na 50 & -4.27 & 0.05 \\
\hline & & & $\log c$ & $\mathrm{CMC}(\mathrm{mmol} / \mathrm{L})$ \\
\hline Water & $\mathrm{Co}(\mathrm{II})$ & ABS Na 50 & -3.57 & 0.27 \\
\hline $0.1 \mathrm{~mol} / \mathrm{L}$ & $\mathrm{Co}(\mathrm{II})$ & ABS Na 50 & -3.56 & 0.27 \\
\hline $1.0 \mathrm{~mol} / \mathrm{L}$ & $\mathrm{Co}(\mathrm{II})$ & ABS Na 50 & -3.96 & 0.11 \\
\hline $3.0 \mathrm{~mol} / \mathrm{L}$ & $\mathrm{Co}(\mathrm{II})$ & ABS Na 50 & -4.07 & 0.09 \\
\hline $6.0 \mathrm{~mol} / \mathrm{L}$ & $\mathrm{Co}(\mathrm{II})$ & ABS Na 50 & -4.25 & 0.06 \\
\hline
\end{tabular}

Next the removal efficiency (\%R) of heavy metal ions in the presence of ABS Na 50 surfactant from the acidic solutions was obtained by means of the static method and compared with the results obtained for the same systems but without the anionic surfactant. Additionally, in the examined solutions the removal efficiency of ABS Na 50 was achieved based on the surface tension measurements in triplicate (ring method) and the concentration of surfactant was calculated using the adsorption isotherms. The removal efficiency of ABS Na 50 surfactant from the $\mathrm{HCl}-\mathrm{M}$ (II) - ABS Na 50 systems in which the surfactant concentration was above and below CMC is presented in Fig. 6.

As can be seen the percentage removal $(\% \mathrm{R})$ of the anionic surfactant ABS Na 50 for the systems under discussion was very high being in the range $83.49-99.95 \%$ (the systems with the initial surfactant concentration $2.55 \mathrm{mg} / \mathrm{L}$,

\section{(a) SORPTION OF ABS Na 50 FROM HCl-ABS Na 50 , HCl-M(II)-ABS Na 50 SYSTEMS, ABOVE CMC}

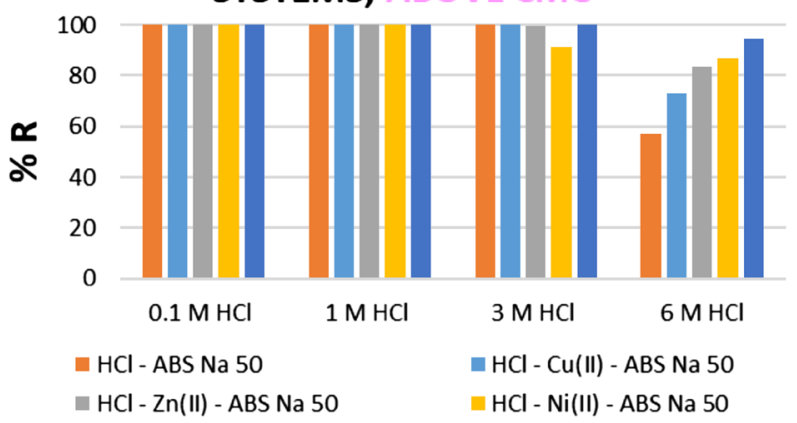

- $\mathrm{HCl}$ - Co(II) - ABS Na 50

(b) SORPTION OF ABS Na 50 FROM HCl-ABS Na 50 , HCl-M(II)-ABS Na 50 SYSTEMS BELOW CMC

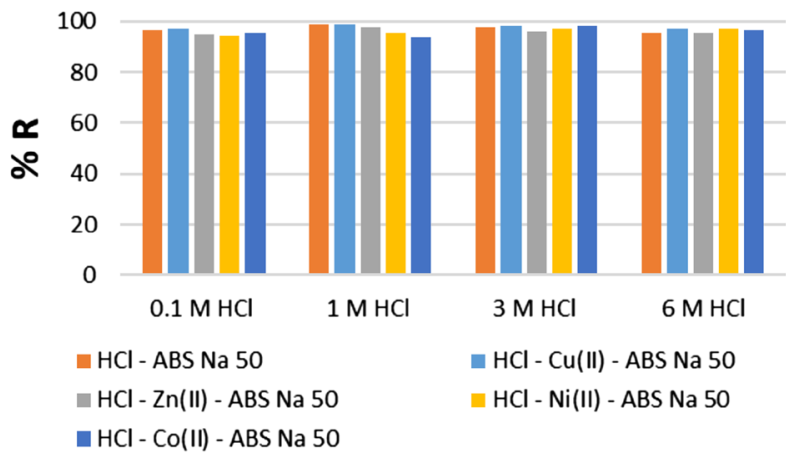

Fig. 6 Removal efficiency of surfactants from the HCl-ABS Na 50, $\mathrm{HCl}-\mathrm{M}(\mathrm{II})$ - ABS Na 50 systems at the surfactant concentration above $(\uparrow)$ and below $(\downarrow)$ CMC

above CMC) and 93.64-98.78\% (the systems with the initial surfactant concentration $0.018 \mathrm{mg} / \mathrm{L}$, below CMC). In the systems of surfactant concentration below CMC the hydrochloric acid concentration $(0.1-6 \mathrm{~mol} / \mathrm{L})$ effect on the surfactant removal is not clearly observed, the percentage removal changes were small whereas in the system above CMC in the solutions containing hydrochloric acid of $6 \mathrm{~mol} / \mathrm{L}$ concentration these values were smaller (percentage removal reduction was observed). Effective surfactant removal of sodium dodecylbenzenesulfonate using different types of ion exchange resins (strongly-MIEX ${ }^{\circledR}, \mathrm{A} 200$, A400, SBW and weakly-A100 basic ion exchange resins) was also observed by Kowalska (2009) but from the solutions containing the surfactant without heavy metal ions. As it was proved the effectiveness of the sodium dodecylbenzenesulfonate removal process increased with the increasing phase contact time and resin dose, depending on the type of 
ion exchange resin (degree of dissociation of ion exchange resin functional groups, size of grains and degree of polymer cross-linking). The sorption ability of ion exchange resins was in the order: MIEX ${ }^{\circledR}>$ SBW $>$ A $400>$ A200 > A 100 . Moreover, the reduction of $\% \mathrm{R}$ values in the $6 \mathrm{~mol} / \mathrm{L}$ solutions could be a result of ionic strength changes. As mentioned by José dos Reis et al. (2004) at the concentrations below CMC a decrease in the repulsive forces between the surfactants polar groups with the increasing ionic strength results in improving their adsorption on the solid surface whereas at the concentration equal to CMC or higher the competition effect between the adsorption and aggregation of surfactant (micelles formation) takes place. When the ionic strength favours stabilization of micelle the competition effect is more significant. After determination of surfactant ABS Na 50 concentration in the systems after the sorption process the concentrations of heavy metal ions were obtained and the \% R values were calculated and presented in Fig. 7.

The preliminary studies presented in Fig. 7 have shown that Lewatit MonoPlus TP 220 is very effective for copper
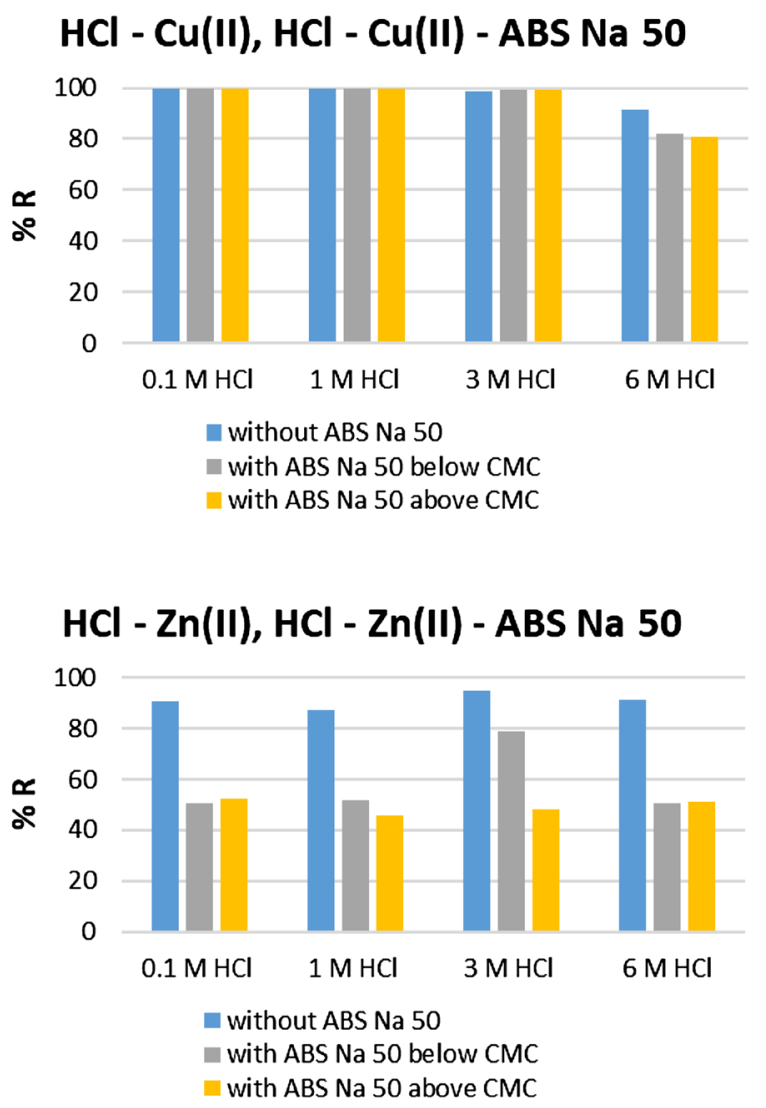

ions removal from the systems of different compositions. In the presence of anionic surfactant the percentage removal of copper(II) ions is still very high in the systems of surfactant concentration below and above CMC similar to $\% \mathrm{R}$ obtained in the systems without the surfactant. Only a slight decrease of copper $\% \mathrm{R}$ was observed in the $6 \mathrm{~mol} / \mathrm{L}$ solutions in the presence of anionic surfactant. In such solutions the competitive sorption could play a more significant role. In the case of other heavy metal ions the presence of surfactant improves the removal efficiency of cobalt(II) and nickel(II) ions and deteriorates \% R for zinc(II). In the solutions without the surfactant the form, in which the heavy metals exist at different concentrations of hydrochloric acid, plays a significant role and affects the removal ability. With the surfactant addition the solution composition changes. In such solutions the surfactant could form aggregates. Sorption of heavy metal ions could take place as unbound metal ions and bound to the surfactant. As it was pointed out by Kowalska (2009) the surfactant sorption consists not only in the ion exchange process, but also the phenomenon of sorption between the hydrophobic surfactant chains and the polymer chains.
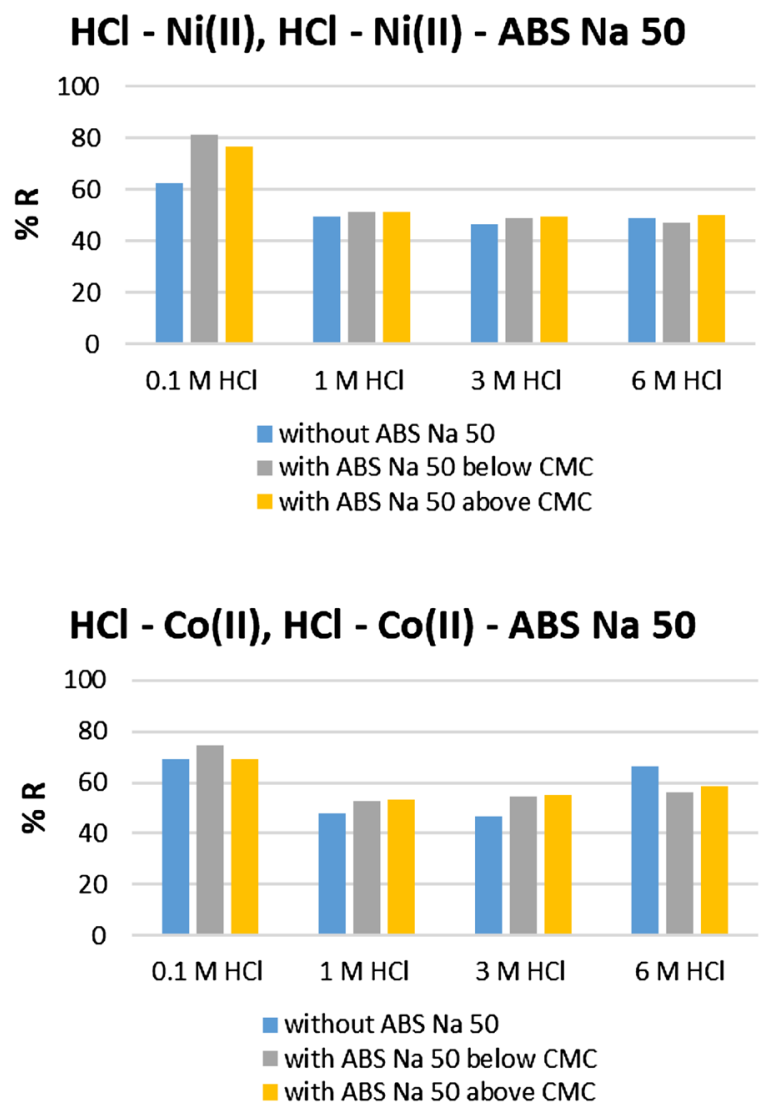

Fig. 7 Removal efficiency of heavy metal ions from the $\mathrm{HCl}-\mathrm{ABS} \mathrm{Na} 50, \mathrm{HCl}-\mathrm{M}(\mathrm{II})$ - ABS Na 50 systems at the surfactant concentration a above $(\uparrow)$ and $\mathbf{b}$ below $(\downarrow)$ CMC 


\subsection{Removal of heavy metal ions from metallurgical wastewater}

The real pregnant leach solution (PLS) were sulfate/chloride leaching liquors obtained after treatment of stainless steel scraps. They were supplied by one of the Polish firms involved in waste treatment. The compositions of PLS vary depending on the batch as a result of changing composition of metal source or leaching procedure. The wastewater is a digestive sewage (used pickling bath) originating from leaching of the metal elements, in particular those rich in nickel and cobalt. Both nickel and cobalt are the basic components of heat-resistant alloys. Besides nickel the heat-resistant nickel alloys contain a significant amount of chromium and such additives as cobalt or copper. The addition of cobalt increases heat resistance and technological properties. Chrome provides good resistance to oxidation at high temperatures and improves plastic properties. The heat-resistant cobalt alloys are characterized, among others, by high thermal conductivity, low coefficient of thermal expansion, high stability, high melting point, and are also resistant to abrasion and thermal fatigue. The main application of heat-resistant alloys is the gas turbine construction industry for aviation, land and sea communication (Davis 2000). The heat-resistant alloys were leached by a mixture of sulfuric(VI) and hydrochloric acids. The content of $\mathrm{H}^{+}$ions in a sewage was equal to $4.6 \mathrm{~mol} / \mathrm{l}$ whereas $\mathrm{pH}$ of wastewaters was -0.3 . The concentrations of the $\mathrm{Cl}^{-}$and $\mathrm{SO}_{4}{ }^{2-}$ ions were 0.337 and $3.22 \mathrm{~mol} / \mathrm{L}$, respectively. The composition of PLS under discussion is presented in Fig. 8a. The metal ions such as $\mathrm{Ni}, \mathrm{Co}, \mathrm{Cu}, \mathrm{Fe}, \mathrm{Cr}, \mathrm{Na}$ were present in the sewage whereas no zinc(II) ions were found. The concentrations of
Fig. 8 Composition a of industrial wastewater originating from leaching of the heatresistant alloys and $\mathbf{b}$ percentage removal $(\% \mathrm{R})$ of heavy metal ions from the solutions without and with the surfactant (a)

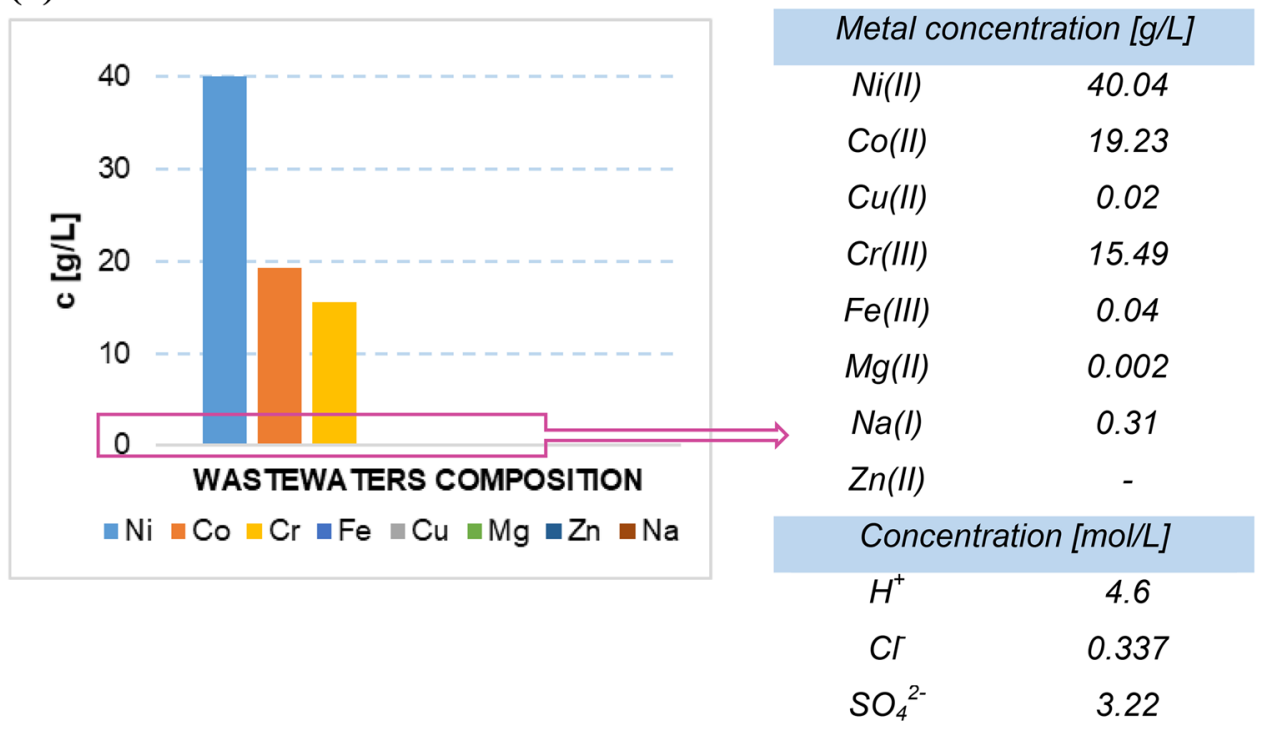

(b)

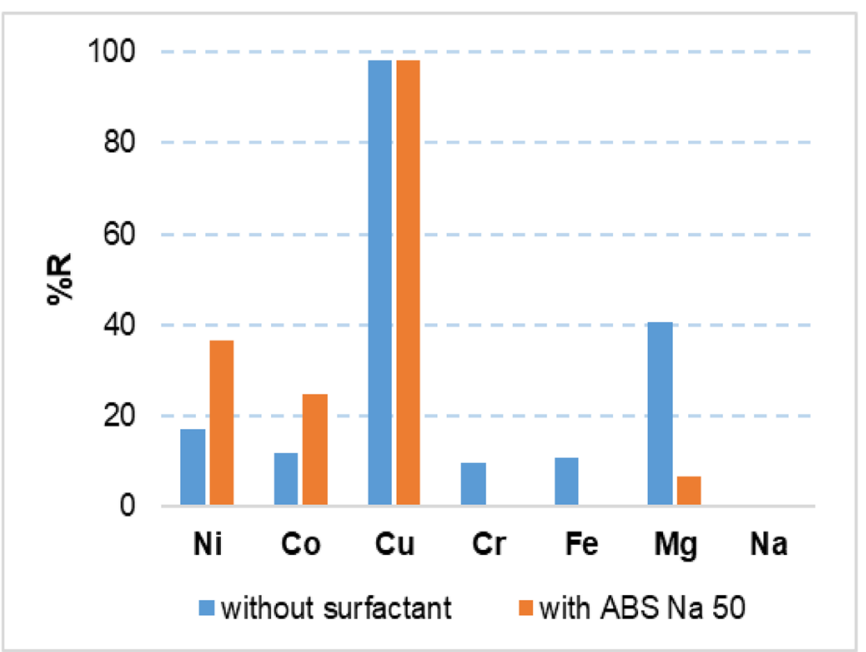


nickel and cobalt are the highest being 40.04 and $19.23 \mathrm{~g} / \mathrm{L}$, respectively whereas the concentration of chromium is $15.49 \mathrm{~g} / \mathrm{L}(<1 \mathrm{mg} / \mathrm{L}$ for the other metal ions).

Then the percentage removal of metal ions was conducted using Lewatit MonoPlus TP 220 from the solutions without and with the surfactant ABS Na 50. As proved Lewatit MonoPlus TP 220 exhibits the best affinity for copper ions. The percentage removal of copper(II) ions was equal to $\% \mathrm{R}=98.27 \%$ whereas these values were in the range from 0 to $40.7 \%$ for the other metal ions. The ABS Na 50 addition increases slightly the percentage removal of cobalt(II) and nickel(II) ions (from 17.07 to $36.65 \%-\mathrm{Ni}(\mathrm{II})$; from 11.91 to $24.89 \%$ - $\mathrm{Co}(\mathrm{II}))$ whereas in the case of copper ions the anionic surfactant effect is not observed $(98.27 \%$ - without the surfactant, $98.13 \%$ - with ABS Na 50).

\section{Conclusions}

The studies on the heavy metal(II) ions removal from the acidic streams on the ion exchanger Lewatit MonoPlus TP 220 lead to the following conclusions:

- Lewatit MonoPlus TP 220 exhibits a very high or high removal efficiency of both heavy metal ions and the surfactant, ABS Na 50 is removed effectively by the ion exchanger under discussion,

- Lewatit MonoPlus TP 220 is an efficient ion exchange resin for copper(II) ions removal from the dilute and strong acidic solutions as well as for cobalt(II), zinc(II) and nickel(II)-The copper removal efficiency was nearly quantitative (\%R close to $100 \%$ ),

- The mechanism of sorption of heavy metal ions on Lewatit MonoPlus TP 220 is of an ion exchange and/or coordination character,

- The CMC value varies depending on the composition of the system. CMC decreases with the addition of strong electrolyte $(\mathrm{HCl})$ and decreases or increases in the presence of heavy metal ions,

- The degree of heavy metal ions removal depends on the concentration of $\mathrm{HCl}$ acid, type of metal ions and concentration of surfactant,

- In the systems containing surfactants, the increase of $\%$ $\mathrm{R}$ of $\mathrm{Co}(\mathrm{II})$ and $\mathrm{Ni}(\mathrm{II})$ was observed compared to the same systems without the surfactant. In the case of $\mathrm{Zn}$ (II) a decrease in its removal efficiency is observed in the systems with the surfactant,

- The degree of heavy metal ions removal on Lewatit MonoPlus TP 220 from industrial wastewaters was nearly quantitative for $\mathrm{Cu}$ (II) ions being in the range of $0-47 \%$ for the other metals. The presence of surfactant increases the degree of $\mathrm{Co}$ (II) and $\mathrm{Ni}$ (II) ions removal, the $\mathrm{Cu}(\mathrm{II})$ ions removal, \% $\mathrm{R}$ remains at a stable high level but it decreases for the other metals.

Acknowledgements The study was financed within the National Science Centre, Poland funds according to Decision No. DEC-2017/01/X/ ST5/01529.

Open Access This article is distributed under the terms of the Creative Commons Attribution 4.0 International License (http://creativeco mmons.org/licenses/by/4.0/), which permits unrestricted use, distribution, and reproduction in any medium, provided you give appropriate credit to the original author(s) and the source, provide a link to the Creative Commons license, and indicate if changes were made.

\section{References}

Akhter, M.S.: Studies on micelle formation and enthalpy of micellization in molten acetamide. Coll. Surf. A 99(2-3), 255-258 (1995)

Atayi, N.Z., Yenigün, O., Asuyay, M.: Sorption of anionic surfactants SDS, AOT, and cationic surfactant Hyamine 1622 on natural soils. Water Air Soil Pollut. 136, 55-68 (2002)

Baldelli, S., Schnitzer, Ch, Shultz, M.J.: The structure of water on $\mathrm{HCl}$ solutions studied with sum frequency generation. Chem. Phys. Lett. 302(1-2), 157-163 (1999)

Budak, T.B.: Removal of heavy metals from wastewater using synthetic ion exchange resin. Asian J. Chem. 25(8), 4207-4210 (2013)

Cross, J. (ed.): Anionic Surfactants: Analytical Chemistry. Marcel Dekker, Inc., New York (1998)

Cserháti, T., Forgács, E., Oros, G.: Biological activity and environmental impact of anionic surfactants. Environ. Int. 28(5), 337-348 (2002)

Cullum, D.C. (ed.): Introduction to Surfactant Analysis. Springer Science + Buisness Media B.V, New York (2012)

Davis, J.R. (ed.): Nickel, Cobalt, and Their Alloys. ASM International, United States of America, Novelty (2000)

Ivanković, T., Hrenović, J.: Surfactants in the environment. Arh. Hig. Rada. Toksikol. 61(1), 95-110 (2010)

José dos Reis, M., Silvério, F., Tronto, J., Valim, J.B.: Effects of pH, temperature, and ionic strength on adsorption of sodium dodecylbenzenesulfonate into $\mathrm{Mg}-\mathrm{Al}-\mathrm{CO}_{3}$ layered double hydroxides. J. Phys. Chem. Solids 65(2-3), 487-492 (2004)

Kołodyńska, D., Sofińska-Chmiel, W., Mendyk, E., Hubicki, Z.: Dowex M4195 and Lewatit ${ }^{\circledR}$ MonoPlus TP 220 in heavy metal ions removal from acidic streams. Sep. Sci. Techol. 49(13), 2003-2015 (2014)

Kowalska, I.: Usuwanie anionowych substancji powierzchniowo czynnych w procesie wymiany jonowej. Ochr. Śr. 31, 25-29 (2009) (in Polish)

Lee, B.-B., Chan, E.-S., Ravindra, P., Khan, T.A.: Surface tension of viscous biopolymer solutions measured using the du Noüy ring method and the drop weight methods. Polym. Bull. 69(4), 471489 (2012)

Markets and Markets.: Surfactants Market By Product Type, Substrates, \& Applications-Global Trends \& Forecasts 2019 (2014)

Matubayasi, N., Namihira, J., Yoshida, M.: Surface properties of aqueous amino acid solutions: I. Surface tension of hydrochloric acidglycine and glycine-sodium hydroxide systems. J. Colloid Interf. Sci. 267(1), 144-150 (2003) 
Muherei, M.A., Junin, R.: Effect of electrolyte on synergism of anionicnonionic surfactant mixture. J. Appl. Sci. 7, 1362-1371 (2007)

Nasr-El-Din, H.A., Al-Othman, A.M., Taylor, K.C., Al-Ghamdi, A.H.: Surface tension of HCl-based stimulation fluids at high temperatures. J. Petrol. Sci. Eng. 43(1-2), 57-73 (2004)

Perkowski, J., Wroński, P., Góralski, J., Szadkowska-Nicze, M.: Adsorpcja dodecylobenzeno-sulfonianu sodu (SDBS) na żelu krzemionkowym z roztworów wodnych. Ochr. Śr. 34(3), 45-50 (2012) (in Polish)

Schramm, L.L. (ed.): Surfactants: Fundamentals and Applications in the Petroleum Industry. Cambridge University Press, Cambridge (2000)

Shah, S.K., Bhattarai, A.S., Chatterjee, K.: Surfactants, its applications and effects on environment. BIBECHANA A Multidiscip. J. Sci. Technol. Math. 7, 61-64 (2011)
Shen, L.-Ch, Nguyen, X.-T., Hankins, N.P.: Removal of heavy metal ions from dilute aqueous solutions by polymer-surfactant aggregates: a novel effluent treatment process. Sep. Purif. Technol. 152, 101-107 (2015)

Staszak, K., Wieczorek, D., Michocka, K.: Effect of sodium chloride on the surface and wetting properties of aqueous solutions of cocamidopropyl betaine. J. Surfactants Deterg. 18(2), 321-328 (2015)

Wołowicz, A., Hubicki, Z.: The use of the chelating resin of a new generation Lewatit MonoPlus TP-220 with the bis-picolylamine functional groups in the removal of selected metal ions from acidic solutions. Chem. Eng. J. 197, 493-508 (2012) 